\title{
SEMINAR KESEHATAN TENTANG STRUKTUR DAN FUNGSI JANTUNG KITA DI GEREJA KRISTEN ALKITAB INDONESIA GADING SERPONG, TANGERANG
}

\author{
Wahyu Irawati ${ }^{1}$, Lastiar Roselyna Sitompul ${ }^{2}$ \\ ${ }^{1,2}$ Program Studi Pendidikan Biologi, Fakultas Ilmu Pendidikan, Universitas Pelita Harapan \\ wahyu.irawati@uph.edu, lastiar.sitompul@uph.edu
}

\begin{abstract}
Abstrak
Pengabdian kepada Masyarakat (PkM) merupakan sarana melaksanakan misi Universitas Pelita Harapan yaitu dengan berkontribusi pada kemajuan ilmu pengetahuan dan kebudayaan yang dipimpin oleh wawasan Kristen alkitabiah serta berpartisipasi secara redemtif dalam pengembangan individu dan masyarakat bagi kemuliaan Allah. Kegiatan PkM dilaksanakan di Gereja Kristen Alkitab Indonesia jalan Raya Kelapa Dua, Ruko Blitz, Blok A No. 28, Gading Serpong, Tangerang-Banten. Analisis kebutuhan berdasarkan angket menunjukkan bahwa jemaat belum memahami secara utuh bagaimana menjaga kesehatan jantung. Kondisi ekonomi jemaat yang rendah membuat jemaat lebih memilih mengkonsumsi makanan murah dan mengenyangkan seperti gorengan tanpa memperhatikan masalah kesehatan jantung. Jemaat suka mengkonsumsi makanan cepat saji yang banyak mengandung lemak demi alasan kepraktisan yang dapat berakibat penyakit jantung. Tujuan dilaksanakannya PkM adalah agar jemaat mengetahui bahwa Allah menciptakan jantung dengan struktur yang mendukung fungsinya agar dapat bekerja dengan baik. Metode PkM adalah ceramah dan tanya jawab. Kegiatan PkM dilaksanakan pada tanggal 19 Oktober 2019 dan dihadiri oleh 25 orang. Berdasarkan hasil angket evaluasi menunjukkan bahwa melalui kegiatan PkM, jemaat memahami struktur dan fungsi jantung yang di ciptakan Allah. Jemaat menyadari bahwa kelalaian manusia dalam menjaga kesehatan dapat mengakibatkan penyakit jantung. Jemaat menyadari bahwa Allah melakukan pemeliharaan sempurna melalui pola hidup yang dapat menjaga kesehatan jantung.
\end{abstract}

Kata kunci: Allah, fungsi, jantung, kesehatan, struktur

\section{PENDAHULUAN}

Jantung adalah organ tubuh yang paling penting bagi manusia karena berperan sebagai alat sirkulasi darah yang membawa oksigen serta nutrisi ke tempat terjadinya proses metabolisme untuk menghasilkan energi. Jantung juga berperan mengangkut sisa metabolisme, membawa hormone ke tempat yang membutuhkan serta mempengaruhi pengaturan suhu tubuh, $\mathrm{pH}$ darah, dan kadar air sel.
Jantung bagaikan sumber kehidupan kita sehingga harus dijaga kesehatannya.

Banyak orang tidak menyadari bahwa Kesehatan kita sangat dipengaruhi oleh Kesehatan jantung. Jantung yang sehat sangat dipengaruhi oleh cara hidup yang sehat seperti pola makan dan pola tidur. Ketidak pedulian masyarakat akan kesehatan jantung terutama tampak pada masyarakat menengah ke bawah yang tidak menjaga pola makan dengan

Kesehatan

385 
memakan makanan berlemak seperti lauk pauk yang mengandung santan, gorengan, lemak daging, lemak ayam, maupun krupuk. Banyak masyarakat tidak mengerti atau tidak perduli bahwa memakan makanan berlemak merupakan tindakan menimbun lemak pada pembuluh darah jantung yang menyebabkan serangan jantung bahkan mengakibatkan kematian diantaranya adalah penyakit jantung koroner atau penyakit arteria koroner.

Penyakit jantung coroner merupakan penyakit yang paling sering menyebabkan serangan jantung pada seseorang yang bisa menyebabkan kematian. Penyebabnya adalah penyempitan pada pembuluh darah koroner, dimana pembuluh ini berfungsi untuk menyediakan darah ke otot jantung. Penyempitan disebabkan oleh tumpukan lemak yang berasal dari makanan yang masuk dalam tubuh. Penumpukan ini juga menyebabkan pembuluh darah koroner menjadi kaku, disebut sebagai aterosklerosis sehingga jantung ttdak dapat menjalankan fungsinya dengan baik.

Penyakit jantung merupakan salah satu penyakit yang paling banyak menyebabkan kematian. Penyakit jantung banyak menyerang manusia dan berakibatkan kematian atau kecacatan tubuh. Hal ini dapat terjadi karena masyarakat tidak memahami struktur dan fungsi jantung sehingga tidak mempunyai kesadaran untuk menjaga kesehatan jantung melalui makanan yang baik. Salah satu tugas Dosen adalah melakukan Pengabdian kepada Masyarakat $(\mathrm{PkM})$ yaitu sebagai nara sumber untuk memberikan pengetahuan kepada masyarakat sesuai dengan bidang keilmuannya. Salah satu target pelaksanaan PkM untuk membagikan informasi tentang struktur dan fungsi jantung yang mempengaruhi Kesehatan tubuh kita adalah Gereja Kristen Alkitab Indonesia.

Gereja Kristen Alkitab Indonesia (GKAI) terletak di jalan Raya Kelapa Dua, Ruko Blitz, Blok A No. 28, Gading Serpong, Tangerang-Banten. Lokasi kebaktian berada di lantai 3 Gedung Fantastic Fitness (Gambar 1). Jumlah jemaat sekitar 50 orang, merupakan warga perantau dari berbagai wilayah dari Indonesia, seperti dari Nusa Tenggara Timur, Nias, Sumatera Utara, Ambon dan Yogyakarta. Jemaat yang ada rata-rata bekerja sebagai pelayan di rumah makan, satpam, dan kasir swalayan. Ada juga jemaat yang bekerja sebagai guru bimbel dan di institusi pendidikan, serta berstatus sebagai mahasiswa (Gambar 2).

Berdasarkan observasi dapat diketahui bahwa Jemaat GKAI didominasi oleh masyarakat ekonomi menengah dengan cara hidup yang sederhana. Hal ini tampak dari cara hidup yang tidak memperhatikan waktui stirahat serta pola makan yang baik. Jemaat yang bekerja sebagai karyawan maupun satpam cenderung makan tanpa memperhitungkan dampaknya terhadap kesehatan jantung. Mereka mengaku memilih makan cepat saji yang murah namun mengenyangkan daripada makanan sehat tetapi tidak mengenyangkan. Jemaat lebih memilih makanan enak dibanding makanan sehat dan jarang memikirkan bahwa makanan yang masuk ke dalam tubuhnya akan mempengaruhi kesehatan jantung.

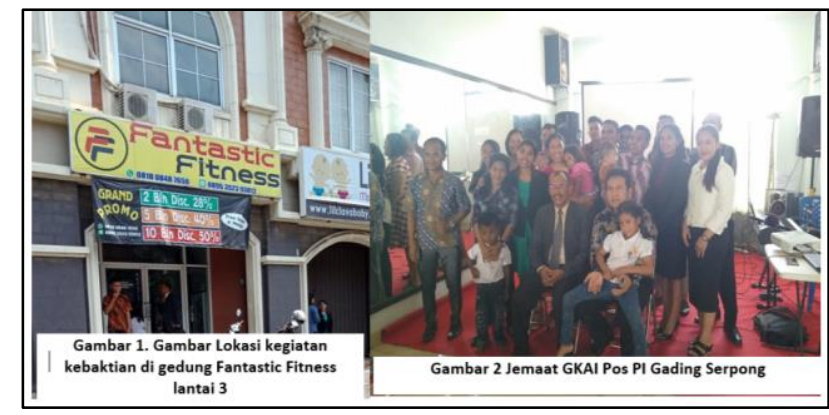

Gambar 10. Lokasi GKAI dan jemaat GKAI

Berdasarkan analisis situasi tersebut maka edukasi tentang kesehatan jantung sangat dibutuhkan. Permasalahan yang muncul adalah: 1) Jemaat belum memahami secara utuh bagaimana menjaga kesehatan jantung, 2) Kondisi ekonomi jemaat yang pas-pasan sehingga jemaat lebih memilih mengkonsumsi makanan yang murah dan mengenyangkan seperti gorengan tanpa memperhatikan masalah kesehatan jantung, serta 3) Jemaat suka mengkonsumsi makanan cepat saji yang banyak mengandung lemak dan suka begadang karena mengerjakan tugas maupun karena kecanduan main games online.

Berdasarkan permasalahan mitra yang ditemukan maka seminar untuk mengedukasi jemaat agar memahami cara memelihara kesehatan jantung sangat dibutuhkan. Kegiatan PkM ini bertujuan agar jemaat mengetahui bahwa Allah menciptakan jantung dengan struktur yang mendukung fungsinya 
agar dapat bekerja dengan baik, jemaat mengetahui bahwa Kejatuhan manusia dalam dosa menyebabkan manusia lalai menjaga kesehatan yang dapat berakibat penyakit jantung dan jemaat mengetahui bahwa Allah melakukan pemeliharaan yang sempurna melalui pola hidup yang dapat menjaga kesehatan jantung.

\section{METODE}

Kegiatan PkM dilaksanakan pada hari/tanggal 28 September 2019, waktu 19.00-20.30 bertempat di Gereja Kristen Alkitab Indonesia Jalan Raya Kelapa Dua, Ruko Blitz, Blok A No. 28, Gading Serpong, Tangerang - Banten. Kegiatan PkM dilaksanakan dalam bentuk ceramah, aktivitas umpan balik/tanya jawab mengenai struktur dan fungsi Jantung. Terdapat dua pembicara PkM yaitu Dr. Wahyu Irawati dan Lastiar Roselyna Sitompul, S.Si., M.Pd. masing-masing sebagai Pembicara pertama dan pembicara kedua. Kegiatan diawali dengan doa pembukaan yang dibawakan oleh pembicara kedua.

Kegiatan diawali dengan menyanyikan lagu pujian dan doa pembukaan (Gambar 2) dilanjutkan dengan kata sambutan dan doa pembukaan oleh Dr. Ashiong P. Munthe sebagai Koordinator Pelayanan di GKAI (Gambar 3).

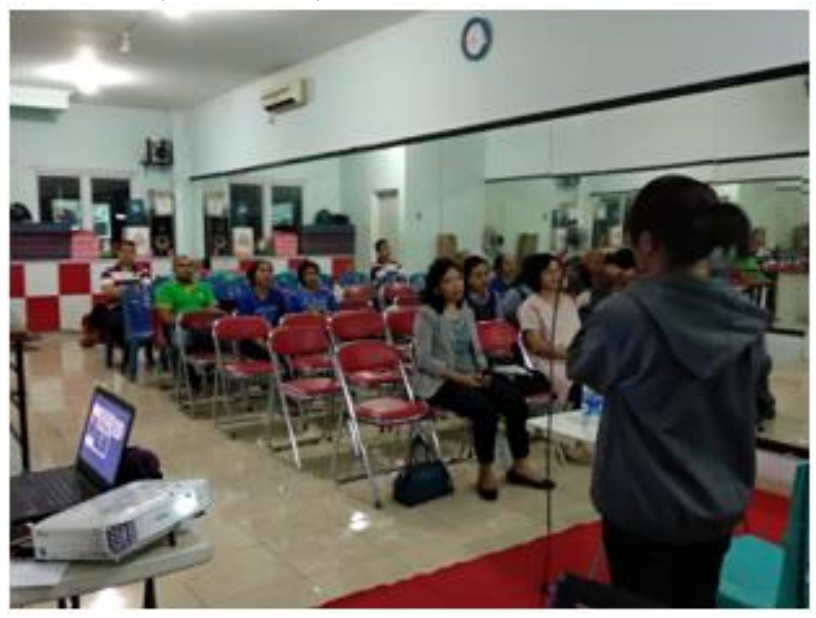

Gambar 2. Jemaat menyanyikan lagu pujian untuk mengawali kegiatan PkM

\footnotetext{
Pembicara pertama mengawali seminar dengan menyampaikan latar belakang dilaksanakanya PkM yaitu untuk menjalankan misi Universitas Pelita Harapan, yaitu berkontribusi pada kemajuan ilmu pengetahuan dan kebudayaan yang
}

dipimpin oleh wawasan dunia Kristen yang alkitabiah serta berpartisipasi secara redemtif dalam pengembangan individu dan masyarakat bagi kemuliaan Allah. Selanjutnya Pembicara menyampaikan tujuan dilaksanakan seminar, yaitu agar jemaat: 1) mengetahui struktur dan fungsi jantung kaitannya dengan kesehatan, 2) mengetahui kaitan pola hidup teratur terhadap kesehatan jantung, serta 3) memberikan kesadaran memelihara tubuh adalah menjaga bait Allah yang harus dilakukan dengan sungguh-sungguh.



Gambar 3. Doa pembukaan dan kata sambutan dari Koordinator Pelayanan GKAI

Pembicara menyampaikan topik utama yang akan disampaikan selama seminar tentang struktur dan fungsi jantung kita adalah agar jemaat:

1. Mengetahui bahwa Jantung diciptakan dengan inisiatif dan keteraturan untuk tujuan yang mulia dalam rancanganNya yang agung.

2. Mengetahui struktur jantung kita.

3. Mengetahui fungsi jantung kita sebagai alat

4. Mengetahui arti tekanan darah berdasarkan cara kerja jantung.

5. Menyadari bahwa kejatuhan manusia dalam dosa menyebabkan manusia tidak menjaga kesehatan jantung sehingga timbulnya penyakit jantung.

\section{HASIL DAN PEMBAHASAN}

Kegiatan PkM dilaksanakan dengan penyampaian materi dilanjutkan sesi tanya jawab yang membahas lima topik (Gambar 4). 
1. Jantung diciptakan dengan inisiatif dan keteraturan untuk tujuan yang mulia dalam rancanganNya yang agung.

Pembicara menyampaikan kepada jemaat bahwa tubuh manusia diciptakan dengan inisiatif dan keteraturan untuk tujuan yang mulia. Keteraturan dapat dilihat dari ciptaan-Nya yang sangat ajaib dalam kehidupan manusia yaitu jantung. Jemaat diajak untuk merenungkan apakah mereka pernah membayangkan struktur jantung mereka masing-masing serta cara jantung bekerja. Pembicara mengajak jemaat untuk melihat struktur dan fungsi jantung mereka melalui penayangan video yang menggambarkan jantung manusia yang sedang berdetak. Jemaat diajak berefleksi untuk merenungkan apakah dengan membayangkan struktur dan fungsi jantung tersebut membuat mereka semakin mengagumi Allah (Gambar 4).



Gambar 4. Jemaat GKAI melakukan tanya jawab

Hasil diskusi menunjukkan bahwa jemaat merenungi karya ciptaan Tuhan yang luar biasa yaitu jantung di dalam tubuh mereka masing-masing. Jemaat tidak pernah membayangkan dan memikirkan berapa kali jantung mereka berdetak dalam satu hari. Melalui penjelasan Pembicara, jemaat baru menyadari bahwa jantung mereka berdetak $100.000 \mathrm{kali} / \mathrm{hari}$ dan memompa 2000 galon darah (7.571 liter). Volume darah yang terpompa sekali kontraksi rata-rata $70 \mathrm{~mL} /$ menit. Melalui diskusi ini, jemaat menyadari bahwa jantung diciptakan dengan inisiatif dan keteraturan untuk tujuan yang mulia.

\section{Struktur jantung kita.}

Pembicara menyampaikan bahwa Allah menciptakan jantung begitu ajaib dengan berat 200 sampai 425 gram, panjang 5 inci, lebar 3.5 inci, depan-belakang 2.5 inci serta dapat berdetak 100000 kali per hari (Mason, Losos, \& Singer, 2011). Jantung manusia terletak pada rongga mediastium dengan posisi miring. Jantung terdiri dari lapisan perikardium viseral dan parietal. Kedua lapisan tersebut dipisahkan oleh cairan pelumas yang berfungsi untuk meminimalisir gesekan yang terjadi akibat gerakan pemompaan jantung (Chalik, 2016). Bunyi detak jantung bagaikan berbunyi lub dan dup. Bunyi lub merupakan hempasan balik darah ke katup-katup AV yang tertutup. Bunyi dup merupakan hempasan balik darah ke katub-katub semilunar yang tertutup (Goodman, 2004). Cacat pada salah satu katup akan menyebabkan kondisi yang dikenal sebagai murmur jantung.

Hasil diskusi dan tanya jawab menunjukkan bahwa jemaat menyadari bahwa jantung mereka mempunyai struktur yang rumit dimana struktur tersebut mendukung fungsi jantung untuk memompa darah. Melalui penjelasan struktur jantung ini jemaat semakin mengagumi ciptaan Tuhan.

\section{Fungsi jantung sebagai alat sirkulasi darah.}

Pembicara menjelaskan tentang fungsi jantung sebagai alat sirkulasi darah. Fungsi peredaran darah manusia adalah sebagai transportasi dari hormon yang telah dihasilkan oleh tubuh, mengangkut oksigen, nutrisi dan zat-zat lainya yang dibutuhkan oleh tubuh. Selain itu sistem peredaran darah manusia memiliki sebagai alat pembuangan limbah sisa dari metabolisme tubuh, menjaga stabilisasi $\mathrm{pH}$ tubuh serta cairan tubuh; memelihara suhu tubuh agar tetap normal, memerangi dan menjaga tubuh dari infeksi baik yang dibawa oleh bakteri, virus dan patogen, sebagai respirasi yaitu memberikan oksigen kepada sel-sel serta membuang karbon dioksida, sebagai pengangkut nutrisi yang diperlukan oleh tubuh dengan membawa zat-zat yang dihasilkan dari makanan, sebagai imunitas tubuh yang dapat melindungi tubuh dari berbagai serangan penyakit, sebagai alat komunikasi seluler sistem peredaran darah, serta sebagai alat termoregulasi tubuh (Jones, et al., 2014). Melalui pembahasan topik ini jemaat menyadari bahwa jantung memiliki fungsi yang sangat penting dalam kehidupan mereka

Pembicara juga menjelaskan bahwa sistem peredaran darah dibedakan menjadi peredaran darah 
sistemik dan pulmonaris. Peredaran darah merupakan sistem peredaran darah mensirkulasikan darah ke seluruh tubuh, sementara perdaran darah pulmonaris mensirkulasikan darah ke paru-paru Jantung memiliki dua fungsi spesifik dalam memompa darah yang kaya akan oksigen ke seluruh tubuh dan secara khusus berkoordinasi dengan paruparu untuk malakukan sirkulasi pertukaran gas karbon dioksida dan oksigen (Wilkin \& Jean, 2015). Melalui penjelasan topik ini, jemaat menyadari bahwa jantung juga dibagi menjadi dua macam peredaran darah yang masing-masing menjalankan peranan penting dalam menunjang kehidupan manusia.

\section{Tekanan darah berdasarkan cara kerja jantung} Pembicara juga menjelaskan cara kerja pemeriksaan jantung dengan menggunakan alat elektrokardiogram (ECG) untuk mendeteksi irama jantung serta cara kerja pengukuran tekanan darah. Elektrokardiogram akan memberikan visualisasi konduksi impuls listrik melalui jantung (Mader \& Windelspecht, 2013).

Denyut jantung manusia dewasa yang normal berada pada kisaran 60-100 per menit. Denyut jantung yang berada di luar kisaran tersebut diasumsikan menunjukkan sejumlah kondisi patologis atau kelainan fungsi pembuluh darah. Hal ini sangat penting diketahui untuk mengidentifikasi jantung yang sehat atau normal. Tekanan darah arteri paling tinggi ketika jantung berkontraksi selama sistol ventrikel, disebut tekanan sistolik. Tekanan diastolik, terjadi ketika tekanan darah lebih rendah namun tetap cukup besar ketika ventrikel berelaksasi. Tekanan darah dapat diukur pada suatu arteri di dalam lengan (lengan berada pada ketinggian yang sama dengan jantung). Tekanan sistolik/diastolik manusia yang dianggap normal berada pada kisaran 100/60 dan 120/80. Tekanan darah 120/80 dan 130/90 akan dikategorikan prehipertensi, sedangkan tekanan darah yang berada diatas 130/90 akan dikategorikan sebagai hipertensi (Jones, et al., 2014).

Melalui diskusi dan tanya jawab, jemaat menyadari bahwa kesehatan jantung dipengaruhi oleh denyut jantung yang normal. Denyut jantung yang sehat mempunyai kriteria tertentu yang berbeda antara laki-laki dan perempuan. Tekanan darah dapat diukur untuk mengetahu kesehatan jantung.
Kelainan jantung secara dini juga dapat diketahui melalui pemeriksaan EKG. Penjelasan topik ini semakin menyadarkan jemaat untuk menjaga pola makan yang dapat mempengaruhi tekanan darah.

\section{Kejatuhan manusia dalam dosa menyebabkan} manusia tidak menjaga tubuh sehingga adanya gangguan timbulnya penyakit jantung.

Pemakalah menjelaskan tentang salah satu penyakit jantung yang sering dialami manusia, yaitu arteroskerosis, yaitu pengerasan arteri akibat akumulasi deposit-deposit lemak disebut plak. Arteri sehat memiliki pelapis bagian dalam yang mulus. Arteri yang rusak bertekstur kasar dan menyebabkan peradangan. Plak tumbuh dengan menggabungkan antara lemak dengan jaringan ikat berserat dan kolesterol tambahan. Seiring pertumbuhan plak dinding arteri menjadi tebal dan kaku dan hambatan arteri meningkat (Yudanardi, Setawan, \& Sofia, 2016).

Aterosklerosis menjadi ancaman bagi kesehatan ketika penumpukan plak menghalangi sirkulasi darah di jantung atau otak. Pembuluh darah yang tersumbat di jantung dapat menyebabkan serangan jantung. Penyumbatan sirkulasi di otak bisa menyebabkan stroke. Penyakit ini dapat muncul karena pengaruh makanan junkfood yang banyak mengandung lemak, diet tinggi lemak, obesitas, diabetes dan merokok. Cara mencegah terjadinya penyakit tersebut adalah menjaga pola tidur, pikiran (Roma 12:12), rutin berolahraga dan khususnya menjaga pola makan. Penyebab utama arteroskerosis disebabkan oleh tingginya kadar kolesterol dan lemak jenuh. Kolesterol dan lemak jenuh banyak ditemukan pada produk hewani, seperti daging, telur, dan susu (Wilkin \& Jean, 2015). Dibutuhkan kesadaran yang dewasa dalam upaya mencegah penyakit arteroskerosis ataupun penyakit lainnya, Hal ini berkaitan dari respon aktif manusia dalam menerima karya keselamatan Kristus dengan menghargai dan merawat tubuh jasmani dan rohani sebagai bait Allah yang kudus.

Salah satu cara untuk mengetahui keehatan jantung kita adalah dengan mengukur detak jantung. Pemakalah Kedua memberi cara praktis mengetahui detak jantung kita dalam kaitannya dengan kesehatan jantung dengan cara mengunduh aplikasi informasi Kesehatan jantung berbasis android pada Kesehatan 
smartphone. Hal ini sangat efisien dan efektif dalam melakukan monitoring kesehatan jantung ataupun melakukan diagnosa kelainan fungsi jantung dengan mandiri. Aplikasi tersebut akan memberikan gambaran mengenai penyakit jantung yang dialami dan memberikan informasi tentang jenis-jenis penyakit jantung beserta gejala, penyebab dan tindakan preventif dalam mengantisipasi penyakit jantung (Indrajani, Bahana, Kosala, \& Heryadi, 2018). Melalui aplikasi tersebut, pemakalah berharap bahwa peserta seminar dapat meningkatkan kesadaran dalam menjaga kesehatan fungsi organ jantung dan sistem perdedaran darah.

\section{Evaluasi Hasil dan Dampak}

Acara berlangsung selama dua jam dengan dihadiri oleh jemaat dan pengerja Gereja yang berjumlah 12 orang. Penyampaian materi berlangsung selama 60 menit dilanjutkan dengan tanya jawab, refleksi, doa penutup, dan penyerahan sertifikat Pembicara pertama dan kedua (Gambar 5 dan 6). Kegiatan PkM diakhiri dengan foto Bersama (Gambar 7).



Gambar 5. Penyerahan sertifikat Pembicara pertama

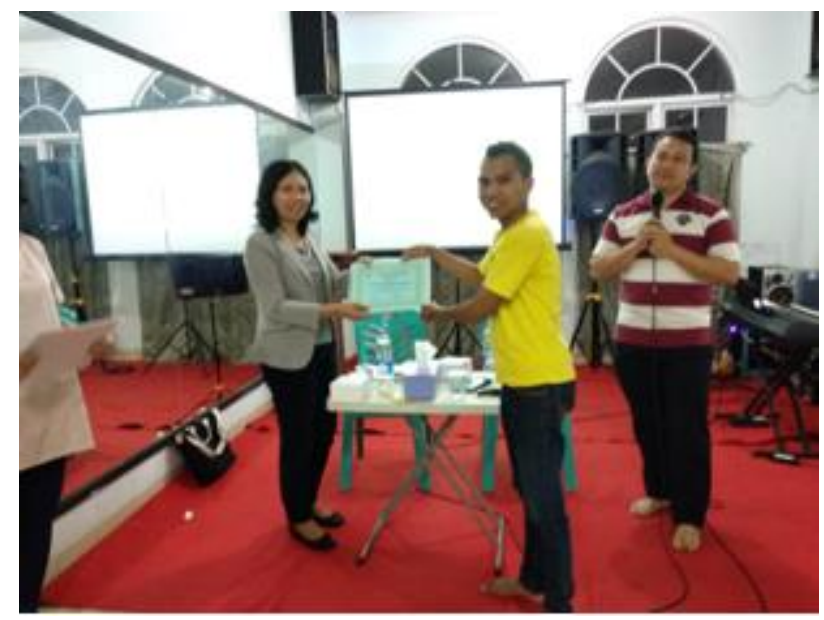

Gambar 6. Penyerahan sertifikat Pembicara kedua

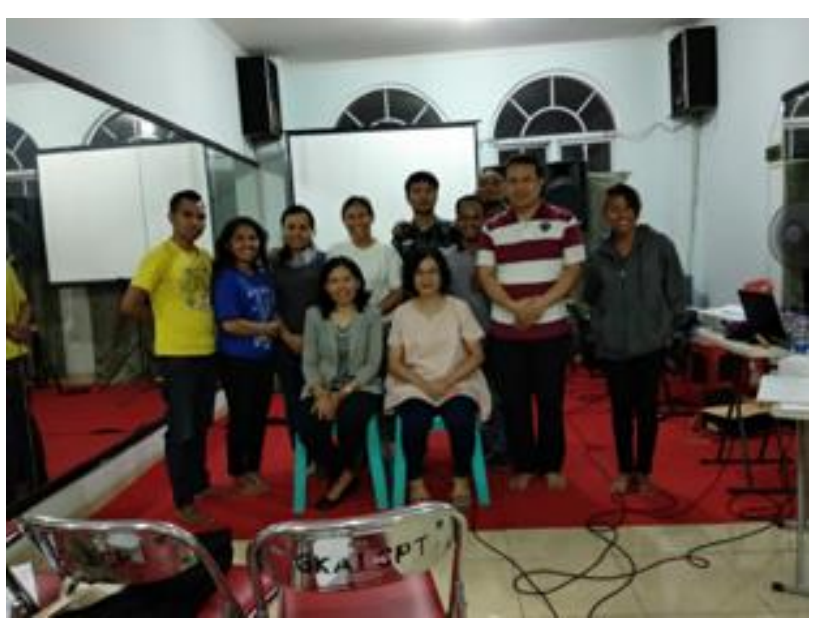

Gambar 6. Foto Bersama jeamaat GKAI di akhir kegiatan PkM

Hasil evaluasi selama seminar dapat dilihat pada tabel 1.

Tabel 1. Lembar evaluasi pelaksanaan PkM

\begin{tabular}{|c|c|c|}
\hline No & Pertanyaan & Jawaban Responden \\
\hline \multirow[t]{8}{*}{1} & \multirow{7}{*}{$\begin{array}{l}\text { dibe } \\
\text { sesu } \\
\text { keb } \\
\text { And }\end{array}$} & Peserta 1: Materi sangat ses \\
\hline & & dengan kebutuhan saya \\
\hline & & Peserta 2: Materi sesuai \\
\hline & & $\begin{array}{l}\text { dengan kebutuhan saya. } \\
\text { Peserta 3. Materi sesuai }\end{array}$ \\
\hline & & \\
\hline & & $\begin{array}{l}\text { kebutuhan saya karena kami } \\
\text { memahami fungsi jantung }\end{array}$ \\
\hline & & $\begin{array}{l}\text { Peserta 4: Materi sangat sesuai } \\
\text { dengan kebutuhan saya. }\end{array}$ \\
\hline & & \\
\hline
\end{tabular}




\begin{tabular}{|c|c|c|c|c|c|}
\hline \multirow[t]{3}{*}{ No } & \multicolumn{2}{|r|}{ Jawaban Responden } & \multirow[t]{2}{*}{ No } & \multirow[t]{2}{*}{ Pertanyaan } & Jawaban Responden \\
\hline & & \multirow[b]{2}{*}{$\begin{array}{l}\text { Peserta 5: Materi } \begin{array}{r}\text { yang } \\
\text { sangat }\end{array} \\
\text { disampaikan } \\
\text { bermanfaat bagi saya. } \\
\text { Peserta 6: Materi sangat sesuai } \\
\text { kebutuhan saya. } \\
\text { Peserta 7: Materi sesuai } \\
\text { kebutuhan saya. } \\
\text { Peserta 8: Materi sesuai } \\
\text { kebutuhan saya. } \\
\text { Peserta 9: Materi sesuai } \\
\text { dengan kebutuhan saya. }\end{array}$} & & & $\begin{array}{lll}\text { kuasai } & \text { adalah kesehatan } \\
\text { jantung } & & \\
\end{array}$ \\
\hline & & & \multirow[t]{2}{*}{3} & \multirow[t]{2}{*}{$\begin{array}{l}\text { Langkah apa } \\
\text { yang anda } \\
\text { ingin lakukan } \\
\text { setelah } \\
\text { mendengarka } \\
\text { n seminar ini? }\end{array}$} & $\begin{array}{l}\text { Peserta 1: Langkah yang saya } \\
\text { lakukan menjaga jantung } \\
\text { Peserta 2: Langkah yang saya } \\
\text { lakukan lebih memerhatikan } \\
\text { kesehatan jantung. } \\
\text { Peserta 3: Langkah yang saya } \\
\text { lakukan adalah memulai } \\
\text { makan yang baik, olahraga, } \\
\text { dan berjalan kaki. }\end{array}$ \\
\hline 2 & \begin{tabular}{l}
\multicolumn{2}{l}{ Apakah } \\
penyampaian \\
materi dapat \\
anda pahami \\
dan materi \\
apa yang \\
paling anda \\
kuasai?
\end{tabular} & $\begin{array}{l}\text { Peserta 1: Iya saya pahami dan } \\
\text { materi yang saya kuasai } \\
\text { adalah tentang menjaga } \\
\text { struktur dan fungsi jantung } \\
\text { dengan cara memperhatikan } \\
\text { pola makan, pola tidur, pikiran } \\
\text { dan olahraga } \\
\text { Peserta 2: Iya saya pahami } \\
\text { tetapi tentang medis kurang } \\
\text { dapat dipahami dan materi } \\
\text { yang paling saya kuasai } \\
\text { adalah fungsi jantung. } \\
\text { Peserta 3: Saya kurang paham } \\
\text { karena bahasa yang digunakan } \\
\text { dan materi yang paling saya } \\
\text { kuasai tentang kesehatan } \\
\text { jantung dengan cara menjaga } \\
\text { pola makan, pola tidur, } \\
\text { olahraga, dan pikiran } \\
\text { Peserta 4: Saya kurang paham } \\
\text { dan materi yang paling saya } \\
\text { kuasai tentang kesehatan } \\
\text { jantung karena dari materi }\end{array}$ & & & $\begin{array}{l}\text { Peserta 4: Langkah yang saya } \\
\text { lakukan adalah pertama pola } \\
\text { makan harus dijaga, kedua } \\
\text { keadaan pola tidur dan } \\
\text { pikiran, dan ketiga olahraga. } \\
\text { Peserta 5: Langkah yang saya } \\
\text { lakukan menjaga kesehatan } \\
\text { jantung. } \\
\text { Peserta 6: Langkah yang saya } \\
\text { lakukan adalah menjaga pola } \\
\text { makan, pola tidur, dan } \\
\text { olahrga. } \\
\text { Peserta 7: Langkah yang saya } \\
\text { lakukan adalah mengatur } \\
\text { pikiran dan olahraga. } \\
\text { Peserta 8: Langkah yang saya } \\
\text { lakukan adalah menjaga pola } \\
\text { makan dan olahraga. } \\
\text { Peserta 9: Langkah yang saya } \\
\text { lakukan adalah menjaga pola } \\
\text { makan, pola tidur, dan } \\
\text { olahraga. }\end{array}$ \\
\hline
\end{tabular}

tersebut saya dapat menjaga pola makan, pola tidur, pikiran, dan olahraga.

Peserta 5: Saya sedikit paham. Peserta 6: Saya paham dan materi yang sangat saya kuasai adalah tentang bagianbagian jantung.

Peserta 7: Saya paham dan materi yang sangat saya kuasai adalah tentang kesehatan jantung.

Peserta 8: Saya paham dan materi yang sangat saya kuasai adalah tentang kesehatan jantung.

Peserta 9: Saya paham dan materi yang sangat saya
Berdasarkan hasil wawancara tertulis dengan sembilan responden menunjukkan bahwa materi seminar tentang 'Struktur dan Fungsi Jantung Kita' sesuai dengan kebutuhan jemaat. Sebagian besar jemaat mengerti tentang materi yang disampaikan terutama tentang fungsi jantung serta cara menjaga kesehatan jantung melalui pola makan, pola tidur, dan berolah raga. Ada dua jemaat yang kurang faham tentang materi yang disampaikan kemungkinan karena banyak istilah teknis yang baru dikenal. Semua responden mengetahui langkah awal yang harus mereka lakukan setelah mengikuti seminar. Semua responden berniat untuk menjaga kesehatan 
jantung dengan mengatur pola makan, pola istirahat, dan berolah raga.

\section{KESIMPULAN}

Kegiatan PkM seminar tentang 'Struktur dan Fungsi Janting Kita' bermanfaat bagi jemaat. Melalui pelaksanaan PkM ini jemaat mengetahui bahwa tubuh manusia diciptakan sebagai mahkota ciptaanNya dengan inisiatif dan dalam rancanganNya yang agung. Jemaat mengetahui bahwa Allah menciptakan struktur jantung dengan fungsinya yang spesifik. Jemaat mengetahu pengertian dan cara kerja elektrokardiogramdan tekanan darah berdasarkan cara kerja jantung. Jemaat menyadari bahwa kejatuhan manusia dalam dosa menyebabkan timbulnya penyakit jantung namun Allah memberikan hikmat akal budi kepada manusia untuk dapat memelihara kesehatan jantung dengan cara hidup yang sehat yaitu mengatur pola makan, pola tidur, dan berolahraga. Jemaat menyadari bahwa Allah memberikan hikmat akal budi kepada manusia untuk dapat memelihara kesehatan jantung dengan cara hidup yang sehat.

\section{UCAPAN TERIMAKASIH}

Ucapan terimakasih disampaikan kepada LPPM Universitas Pelita Harapan yang telah memberikan ijin pelaksanaan PkM ini dengan No PkM: PM-097-M/FIP/X/2019.

\section{REFERENSI}

Campbell,N.A., J.B. Reece, and L.B. Mitchell. (2010). Biologi. Jilid 1-3. Jakarta: Erlangga.

Chalik, R. (2016). Anatomi fisiologi manusia . Jakarta: Pusdik SDM Kesehatan Badan Pengembangan dan Pemberdayaan Sumber Daya Manusia Kesehatan.
Ganong, W. F. (2008). Fisiologi kedokteran. Jakarta: Penerbit buku kedokteran

Goodman, A. A. (2004). Understanding the human body: An introduction to anatomy and physiology. United States of America: THE GREAT COURSES.

Indrajani, Bahana, R., Kosala, R., \& Heryadi, Y. (2018, November 13). Aplikasi informasi kesehatan dan diagnosa penyakit jantung berbasis android. Seminar Nasional Teknologi Informasi, Komunikasi dan Industri (SNTIKI-10), 10-16. Diambil kembali dari http://ejournal.uinsuska.ac.id/index.php/SNTIKI/article/view/5811

Jones, C. M., Baker-Groberg, S. M., Cianchetti, F. A., Glynn, J. J., Healy, L. D., Lam, W. Y., . . McCarty, O. (2014). Measurement science in the circulatory system. Cellular and Molecular Bioengineering, 7(1), 1-14. doi:10.1007/s12195013-0317-4.

Mader, S. S., \& Windelspecht, M. (2013). Biology eleventh edition. Unites State of America: McGraw Hill.

Mason, K. A., Losos, J. B., \& Singer, S. R. (2011). Biology. New York: McGraw-Hill.

Wilkin, D., \& Jean, B. (2015). Human biology. United States of America: CK-12 Foundation.

Yudanardi, M. R., Setawan, A. A., \& Sofia, S. N. (2016). Hubungan tingkat adiksi merokok dengan derajat keparahan aterosklerosis pada pasien penyakit jantung koroner. JURNAL KEDOKTERAN DIPONEGORO, 4, 1207-1213. doi:http://ejournals1.undip.ac.id/index.php/medico 